\title{
Prediking oor die profetiese stof van die Ou Testament
}

HF van Rooy, Potchefstroom

ABSTRACT
Preaching on the prophetic books of the Old Testament
In this paper practical guidelines are given for preaching on the
prophetic books of the Old Testament. It deals with the prophetic
office and pays special attention to Carroll's theory of the influence
of cognitive dissonance on the work of a prophet and to Overholt's
view of the prophetic process and the interaction between a prophet
and his audience. In the guidelines, attention is given to the histori-
cal situation of the prophet and his audience and the circumstances
leading to a particular prophetic utterance, rhetorical devices, the
interaction between the prophet and his audience, the meaning of
the message for Israel against the background of the message of
the Old Testament, the redaction of the book and the audience of
the redaction, the fulfilment of the prophecy, the message for
today, always taking into account the difference in situation, the
revelation about God and a possible eschatological message.

\section{INILEIDING}

Die doel van die artikel is om praktiese riglyne te gee oor prediking uit die profetiese stof van die Ou Testament. Daarvoor is dit nodig dat daar aandag gegee moet word aan wat onder profetiese stof verstaan word, aan wat profesie is en hoe profetiese literatuur beskou moet word. Daar sal ook aandag gegee word aan valse profesie en enkele teorieë wat vir die prediking belangrik is. Daarna sal die riglyne aan die orde kom. Daar sal afgesluit word met 'n kort voorbeeld van hoe sulke riglyne op 'n spesifieke gedeelte toegepas kan word, naamlik op Esegiël 29 : 1 - 16 .

Die belang van die prediking oor die profete mag nie onderskat word nie. Daar word dikwels gesê dat die kerk se prediking profetiese prediking moet wees - maar dan moet onthou word dat profetiese prediking egter pastorale prediking moet wees, pastoraal in die sin dat dit betrek is op die situasie van die hoorder (Gerssen, 1983:105). Hoe belangrik die profete binne die opset van die Ou Testament is, blyk uit die uitspraak van Vriezen dat die profeet vir die Ou Testament die mees tipiese en sentrale figuur is (1966:249). In elk geval is dit so dat daar geen geskrifte in die Bybel is wat die mens so direk met die werklikheid van God konfronteer nie en wat die mens so forseer om sy aardse en godsdienstige persepsies, wat sy lewe beheer, te ondersoek as juis die profetiese literatuur nie (Blenkinsopp, 1984:18). 
Daar word gekonsentreer op die klassieke profete, wat ook die Skrifprofete genoem word, alhoewel die belang van vroeere profete, na wie daar in die historiese boeke van die Ou Testament verwys word, nie miskien word nie (vgl. Wilson, 1978 vir 'n oorsigtelike bespreking van die vroeere profete).

Die probleme van die prediking oor die ou Testament vir die Christelike kerk in die algemeen kan hier nie breedvoerig behandel word nie. Algemene besprekings word aangetref by Verhoef (1977), Helberg (1983) en Preuss (1984). Veral laasgenoemde se bree bespreking van die verskillende maniere waarop die Ou Testament in die prediking benader word, is baie belangrik (Preuss, 1984:61-164).

\section{PROFESIE EN DIE PROFETIESE STOF}

\subsection{Inleiding}

Daar bestaan 'n verskeidenheid van sieninge oor wat 'n profeet of profesie is. Dit hou verband met hoe die taak en roeping van 'n profeet gesien word. Moet die profeetskap byvoorbeeld as 'n vaste amp gesien word? Is dit nie dalk eerder so dat 'n profeet eerder in 'n krisissituasie optree, sodat hy gesien moet word as 'n wagter wat moet waarsku, wie se optrede eintlik buite die normale bedieningspatrone val nie (Aalders. 1983:10)?

\subsection{Die profetiese stof}

Wat die onderskeid van die verskillende soorte stof in die Ou Testament met die oog op die prediking betref, bly dit goed om 'n oomblik aandag te gee aan die onderskeidinge wat Dijk (1955) in die verband getref het. Hy het sewe soorte stof onderskei in die Ou Testament, naamlik historiese, tipies-simboliese, liriese, chokmatiese, profetiese, apokaliptiesprofetiese en spesiaal-Messiaanse stowwe (1955:197-198). Wanneer dit gaan om die stof wat in die profetiese boeke in die Ou testament - die latere profete - aangetref word, is die laaste drie tipes stof van Dijk teı sake. Die profetiese stof omskryf hy as dit wat die profesiee behandel wat die lig van die Wet van die Here laat val op die geskiedenis, dit wat steeds spreek en wat die nabye en verre toekoms belig. Die apokaliptiesprofetiese stof, wat hy bemerk in die boeke van Daniel en Esegiel en wat die spesiale vorm van die apokalips vertoon, sien hy as 'n aparte getuienis oor die dinge wat gaan gebeur. Hy behandel die spesiaalMessiaanse stof apart om die onderskeid tussen direkte en indirekte profesie te belig en om hom te besin oor hoe die lyn na die vervulling getrek moet word.

Hier word onder die profetiese stof dit verstaan wat in die profetiese boeke van die Ou Testament aangetref word. Daar moet net in gedagte gehou word dat dit verskillende soorte stof insluit, wat elkeen na sy eie aard hanteer moet word. Dit gaan dus oor die klassieke profete. Daaronder word verstaan die literatuur van die latere profete, wat tussen die agste en vyfde eeue voor Christus opgetree het. Hierdie boeke is versamelings van die uitsprake van die profete, wat dus aan spesifieke persone verbind is. Daarin word veral op Israel as geheel gekonsentreer 
(vgl. Wolff, 1978:17-19). Hierdie boeke is deur Israel bewaar omdat hulle die uitsprake daarin as normatief beskou het (Zimmerli, 1978:185).

\subsection{Verskillende sieninge oor wat profesie is}

Profete is al beskou as bloot toekomsvoorspellers, as groot denkers, as kampvegters vir sosiale geregtigheid, as skeppers van 'n verhewe monoteisme (Odendaal, 1985:7), as predikers en getuies (Vriezen, 1966:253), as charismatiese ontvangers van visioene en gesproke boodskappe, as skrywers van pragtige Hebreeuse poësie, as onafhanklike denkers wat aan dit wat hulle ontvang het, 'n rasionele vorm gegee het (Koch. 1982:vii). Hoe dit ook al gesien word, moet dit in gedagte gehou word dat die profete tussengangers was tussen die menslike en goddelike wêrelde. Hulle is die kanale waardeur goddelike boodskappe die mens bereik en deur wie die mens tot God kan nader (Wilson, 1978:8).

Hierdie opsomming wys dat daar ' $n$ verskeidenheid van sieninge is oor wat die profesie is, uitgaande natuurlik ook van 'n verskeidenheid van standpunte. Aan die een kant van die spektrum staan die standpunt van iemand soos Dijk, wat nie 'n Ou-Testamentikus is nie, maar die saak bekyk vanuit die hoek van 'n homileet. Hy beskou profesie as die verkondiging of openbaring van die raad van God oor die wêreld en in die besonder oor sy volk en dit op die grondslag van die Tora. Volgens hom gaan die profete uit van dit wat God in sy wet en deur die diens van sy knegte, soos Moses, beveel het. Profesie laat die soeklig van die wet val op die verlede, dit preek die heilige wil van God vir die hede en maak God se raad vir die toekoms bekend (Dijk, 1955:231). Hiervolgens gaan die wet die profete vooraf, terwyl daar baie geleerdes is aan die ander kant van die spektrum wat die wet na die profete wil plaas in die ontwikkeling van die godsdiens van Israel. Ander wil die profete nie so aan die wet verbind nie, maar wil eerder hulle optrede sien in die lig van die verbond. So sien Odendaal die profete as mense deur God gestuur om as sy boodskappers die verbondskarakter van die volk te handhaaf (1985:9). Die optrede van die profete is dan diensbaar aan die verbond en die verbond moet weer gesien word in diens van die oprigting van Jahweh se ewige en universele koninkryk. In hierdie opsig is die profetiese prediking sterk eskatologies gerig (Odendaal, 1985:11). Dit is ook moontlik om die profete nie aan iets spesifieks, soos die wet of die verbond, te verbind nie. Vriezen sẽ dat profesie na sy wese in ooreenstemming is met die wese van die Jahwisme (1966:251).

'n Profeet se gesag word dikwels aan sy roeping verbind (vgl. bv. Aalders, 1983:10). In die roepingsgedagte moet die saak van 'n sterk persoonlike band tussen die profeet en God wel klem ontvang (Vriezen, 1966:251). In die roeping word die persoon en karakter van die profeet egter nie. gekanselleer nie (Wolff, 1978:20-21).

Die profete is beheer deur die sentrale bewussyn dat hulle ontvangers en verkondigers was van 'n onontwykbare goddelike woord (Odendaal, $1985: 8$ ). Hulle openbaar God in sy persoonlike, lewende verhouding met sy volk, in sy heiligheid waardeur Hy Israel nie spaar nie, in sy geregtigheid, waardeur Hy oordeel en toekomstige heil laat verkondig en in sy liefde wat bly stry om die heil van sy volk (Vriezen, 1966:255).

\section{4 - In die Skriflig 1989, 23 (1)}


Die taak van die skrifprofete is baie sterk aan die geskiedenis verbind. Die ontstaan van die profetiese amp moet ook aan die ontstaan van die koningskap van Israel verbind word (Le Roux, 1986:123). Al gaan dit dikwels in die profete om God en sy volk, kan die kontoere van die wëreldgeskiedenis van daardie tyd agter hierdie drama gesien word (Le Roux, 1986:125). Vir hulle is dit Jahweh wat deur die geskiedenis spreek (Zimmerli, 1978:191). Die profete sien alles vanuit die profetiese perspektief, waarin hede, verlede en toekoms omvat is. God is by al hierdie dinge betrokke en het alles onder beheer (Le Roux, 1986:126). In hierdie perspektief word verskillende gebeurtenisse wat in die toekoms lẽ, tot een saamgetrek (Helberg, 1983:50). Hulle hou hulle besig met die nuwe wat Jahweh gaan bring, met die einde van die ou dinge en die nuwe wat daarop gaan volg (Wolff, 1978:22-24). Hulle maak dit duidelik dat die oordeel wat gaan kom, geregverdig is (Wolff, 1978:26).

Dit is so dat die profete nie juis optimisties oor die toekoms was nie hulle het die religieuse, sosiale en sedelike wanpraktyke baie skerp aangeval en so ook die staatsbeleid van hulle tyd. Tog speel die element van hoop ' $n$ beduidende rol in hulle optrede. Dit is juis hierdie element wat hulle werk dikwels sterk aan die Nuwe Testament bind (vgl. Bright, 1976b:15). Al was hulle nie optimisties oor die toekoms nie, was hulle optrede op die toekoms gerig. Hulle het dit wat sal gebeur op die hede gebaseer, terwyl hulle gevolgtrekkings gemaak het uit die morele optrede van die mense rondom hulle (Koch, 1982:1-2). Schmidt (1971:632) wil dit egter net mooi andersom sien. Hy sê dat die profete uit die perspektief van die toekoms na die hede kyk. Die toekoms bepaal eintlik so die hede.

Daar kan 'n aantal basiese trekke van die profetiese boodskap aangedui word. Koch (1983:201-202) onderskei vier sulke basiese trekke:

- Die oortuiging dat daar net een God is en dat op grond van sy unieke soewereiniteit, alle afgodery verwerp moet word.

$\star$ God se openbaring word gemaak op die vlak van spraak, in die beloftewoord en in die wet.

* Vir die praktiese lewe is morele optrede van die grootste belang. Die soeke na geregtigheid tussen mense is die bewys van ware geloof. Dit is belangriker as die godsdienstige seremonies.

^ Daar is 'n eskatologiese on rustigheid met die huidige stand van lyding op die wêreld. Daarom kyk die profete na die verlossing wat God gaan bring op die dag van Jahweh.

\subsection{Verskillende teorieë oor profetisme wat vir die prediking van belang is}

Dit is baie belangrik om raak te sien dat daar 'n interaksie tussen die profeet en sy gehoor was. Die profeet wou sy hoorders daarvan oortuig om hulle wee te verander. Hierdie woord is egter dikwels nie aanvaar nie, onder andere weens die konteks waarin die hoorders hulle bevind het (Le Roux, 1986: 152). Binne 'n sekere sosiale konteks was daar sekere norme waaraan ' $n$ profeet se optrede gemeet is. Wanneer 'n profeet te radikaal hiervan afgewyk het, is sy boodskap nie aanvaar nie (Wilson, 
1978:9). Daar moet ook daarmee rekening gehou word dat profesie in wese voorwaardelik is. Die vervulling van 'n belofte of 'n oordeelsuitspraak hang saam met die reaksie van die hoorders (Helberg, 1983:50).

Wat verskillende teoriee betref wat met die wisselwerking tussen die profeet en sy gehoor werk, word hier kortliks stilgestaan by die teoriee van Overholt en Carroll.

In verskillende publikasies het Overholt gewys op die belang van die rol van die gehoor in die profetiese proses (1977, 1979a, 1979b, 1981, 1982). Hy het gewys op twee aspekte van die reaksie van die gehoor op die profetiese boodskap, wat vir die bestudering van die profesie belangrik is. Die een aspek is die wisselwerking wat daar tussen die profeet en sy adres is en waaraan Overholt baie aandag gegee het (in al die bogenoemde werke behalwe 1979b). Die ander saak is iets wat hy in die boek van Jeremia aangetref het, naamlik dat in die profetiese uitsprake aanhalings aangetref word waarin die gesindheid van die hoorders weergegee word. Hy wys daarop dat Jeremia meermale die woorde van sy gehoor aanhaal (1979b:262ff). Hierdie aanhalings wys dan hoe die profeet die gesindheid van sy gehoor gepeil het - dit kan gesien word as sy interpretasie van die vox populi. Baie van die aanhalings kon natuurlik meer retories van aard gewees het, maar is tog 'n belangrike aanduiding van hoe die profeet sy gehoor gelees het (vgl. Overholt, 1979b:273).

Wat die eerste aspek betref, wys hy daarop dat die gesag van die profeet van twee sake afhanklik was, naamlik 'n openbaring van Jahweh aan die een kant "and acknowledgment within a particular social context by some segment of his audience" (1979a:518). In die profetiese proses is daar dan drie elemente wat 'n rol speel, naamlik die bonatuurlike wat 'n boodskap het, die profeet wat die boodskap lewer en die hoorders wat die boodskap hoor. Wat veral van belang is, is die interaksie tussen die drie elemente (Overholt, 1977:132f). Daar is verder ook twee norme waaraan die gemeenskap veral die boodskap van die profeet toets, naamlik dat sy boodskap 'n kontinuering moet wees van die gemeenskap se sosioreligieuse tradisies en dat dit relevant moet wees in die huidige sosiopolitieke situasie (Overholt, 1977:132). In hierdie onderskeiding gaan Overholt verder as Crenshaw (1971:3), wat wel vier stadia in die profetiese funksie onderskei, maar wat nie soveel klem lê op die interaksie tussen die profeet en sy gehoor nie. Die vier stadia wat Crenshaw onderskei, is die profeet se geheime ervaring met God, die profeet se interpretasie daarvan in die lig van sy geloof, die proses van intellektuele hersiening en dje kunstige ontwikkeling van die boodskap.

Vir die teorie van kognitiewe dissonansie in die profetiese literatuur is die werk van Carroll (1979) belangrik. Kognitiewe dissonansie is die gevolg van 'n konflik wat daar in 'n mens se lewe kom as jou verwagtinge en die werklikheid van jou situasie met mekaar in stryd is. Dit het byvoorbeeld 'n belangrike rol gespeel in die optrede van die teruggekeerde ballinge, wie se verwagtinge, aangewakker deur die profesieè van Deutero-Jesaja, nie vervul is nie. Haggai en Sagaria se optrede moet in hierdie konteks verstaan word. Die min mense wat uit die ballingskap 
teruggekeer het, het in die land met 'n vyandige gemeenskap in aanraking gekom en het as gevolg van hulle omstandighede en teleurgestelde verwagtinge apaties gestaan teenoor die bou van die tempel. Haggai en Sagaria het die tempelprojek beskou as 'n noodsaaklike stap in die verwerkliking van die verwagte verlossing. Haggai se optrede kan gesien word as ' $n$ poging om hierdie kognitiewe dissonansie teen te werk deur die mense van sy tyd te wys op die belang van die tempelbou en om hulle so aan te spoor om weer aan die werk te spring. Vir ' $n$ volledige bespreking van die saak van kognitiewe dissonansie in die boek van Haggai kan verwys word na Van Rooy (1988a).

Hierdie teorie van Carrol kan goed inpas in die skema van Overholt. Die kognitiewe dissonansie werk op die vlak van die wisselwerking tussen die profeet en sy gehoor en dit maak die oog oop vir die verwagtinge en die teleurstellings van diegene tot wie die profete hulle gerig het.

\subsection{Ware en valse profesie}

Hierdie is so 'n omvattende onderwerp dat hier slegs kortliks daarna verwys kan word. Daar word dikwels in die Ou Testament na valse profete en valse profesie verwys. Soms wil 'n mens die valse profete eenvoudig van kwaadwilligheid beskuldig, van doelbewuste verdraaiing van die profetiese boodskap. Tog moet die vraag gevra word of die saak so eenvoudig is. Is dit nie soms eerder so dat die valse profeet aan 'n algemeen-geldige waarheid vasgryp en dit dan op die verkeerde situasie toepas nie (vgl. Gerssen, 1983:105)? By Jeremia kom dit duidelik na vore dat hy die toekoms van die volk heeltemal anders as sy tydgenote gesien het. Tog het hy en sy opponente sterk teologiese sieninge gehad (vgl. Bright, 1976b: 16-17).

'n Deel van die agtergrond van die valse profesie kan gesoek word in 'n verstarring wat daar ten opsigte van die Heilsgeskiedenis ingetree het. Hulle het begin om die Heilsgeskiedenis te sien as die waarborg dat God sy volk nooit in die steek sal laat nie, ongeag hulle eie optrede. Dit is hierteen dat die ware profete hulle verset het. Hulle het so eintlik die Heilsgeskiedenis gerelativeer deur daarop te wys dat die volk eintlik 'n streep deur hulle verlede met God getrek het (vgl. Le Roux, 1986:127-129).

Die stryd tussen ware en valse profete het baie bygedra tot die lyding van die ware profete. Dit was deel van die weerstand teen die profete, waarin die "amptelike" tempelprofete 'n groot rol gespeel het (Wolff, 1978:28-30). Dit moet ook vandag nog onthou word dat die wêreld lief is daarvoor om die waarheid te kruisig (Herrmann, 1971:664).

\subsection{Profetiese literatuur}

Dit is so dat die profete in 'n bepaalde tyd opgetree het en dan hulle prediking op die man af was en dus nie tydloos is nie (Dijk, 1955:232). Mondelinge prediking was die uitstaande kenmerk van hulle roeping en werk (Tucker, 1978:311). Tog is daarmee nie die laaste woord oor die profetiese literatuur gesé nie. Die profeet het in 'n bepaalde situasie opgetree - maar sy woorde is opgeteken om ook vir 'n latere gehoor 'n boodskap te bring. Dit skep die moontlikheid dat 'n profetiese uitspraak nuut op 'n nuwe situasie toegepas kan word. Die Ou Testament 
bevat nie maar die oorspronklike woorde van die profete nie, maar daar was 'n proses van redaksie, waarin daar ook sprake van verwerking van die materiaal kan wees (vgl. Clements, 1982:119).

Wat presies die rol van die leerlinge van die profete in die proses was, is nie altyd ewe duidelik nie. Dat hulle daarin wel 'n belanrike rol gespeel het, moet aanvaar word (vgl. Vriezen, 1966:252).

Daar moet ook in gedagte gehou word dat alles in die profetiese literatuur nie op dieselfde wyse benader kan word nie. Daar is profeteverhale met biografiese en outobiografiese materiaal, roepingsberigte, beskrywings van tekenhandelings, gebede en profetiese uitsprake (Odendaal, 1985:9). Vriezen en Van der Woude onderskei bloot profesieë, confessiones en historiese verhale oor die profete (1976:218-219). Profesie is veral prediking tot die volk, meestal in digterlike vorm. Die confessiones is persoonlike ontboeseminge van die profeet veral oor ervaringe met sy roeping en rondom die vervulling van sy amp. Daar kan hier onderskei word tussen meer outobiografiese stof oor die roeping, persoonlike visioene en ervaringe van die profeet en liriese ontboeseminge van die profeet. Die historiese verhale is gewoonlik deur iemand anders oor die profeet geskryf.

Die vraag na die verhouding tussen 'n spesifieke profeet en die boek waarin sy uitsprake opgeneem is, moet ook aandag kry. As voorbeeld kan verwys word na die boek van die profeet Jeremia, waaroor elders breedvoerig gehandel is (vgl. Van Rooy, 1988b). Oor Jeremia is daar wyd uiteenlopende standpunte. Aan die een kant staan byvoorbeeld Carroll (1981:9) en Nicholson (1970:136), wat weinig van Jeremia self in die boek vind. Aan die ander kant staan weer Bright (1976a:333) en Blenkinsopp (1984:155), wat meen dat Jeremia geweldig baie biografiese materiaal bevat.

Brueggemann het 'n standpunt wat probeer om die middeweg tussen die twee uiterstes te volg en vat sy siening van die verhouding tussen die historiese Jeremia en die weergawe in die boek soos volg saam (1983:132): "We have an imaginative literary construction governed by a powerful person of memory". Hy sien ook 'n teologiese intensie agter die boek, wat dan wel breer gaan as bloot 'n weergawe van dit wat Jeremia in sy eie tyd gedoen, ervaar en gesẽ het. Die redakteurs van die boek wou Jeremia in die tyd van die ballingskap voorhou as 'n model of paradigma van wat 'n profeet en 'n gelowige is en wat Israel kan wees. So was hulle kreatiewe teoloe wat geloof wou bou in die tyd van Israel se grootste krisis (1983:132). Dit hou dus in dat die prediking van die boek vir 'n volgende geslag nie losgemaak kan word van dit wat Jeremia gesê en gedoen het nie. Die standpunt van Childs hieroor kan ook in ag geneem word, al is daar ook baie kritiek teen sy sogenaamde kanonkritiese benadering tot die $\mathrm{Ou}$ Testament. Hy lẽ egter tereg klem daarop dat profetiese uitsprake wat tot een geslag gerig was, deur 'n proses gevorm is om weer deur 'n volgende geslag gebruik te word (1978:47; die artikel bied 'n goeie samevatting van hoe hy die werking van die kanoniese proses by die profete sien). 
Daar moet ook rekening gehou word met sekere vaste vorme wat meermale in die profetiese boeke voorkom wanneer daar met die profetiese literatuur as literatuur erns gemaak word. Hier kan daar wel nie op sulke vorme volledig ingegaan word nie. Tog is dit belangrik om te let op vaste norme soos die gerigsaankondiging, die heilsbelofte, die heilsaankondiging, die krygsgodhimne, die rib-uitsprake (regsaak tussen God en volk) (vgl. Le Roux, 1986:149-150. Helberg. 1983:49 en Tucker. 1978:39-40).

\subsection{Profesie en die kerk}

Daar is reeds op gewys dat daar in die tyd van Jeremia 'n stryd was tussen twee botsende sieninge van die verbond. Bright wys daarop dat die kerk vandag ook leef met sowel die beloftes as die eise van die verbond, dus met albei die verbondspatrone (1976b:197-198). Daar is steeds 'n spanning tussen belofte en eis. Aan die een kant staan die onvoorwaardelike genade in Christus, die onvoorwaardelike beloftes waarop die gelowige kan vertrou. Aan die ander kant die eis dat die gelowige aan God gehoorsaam moet wees as die soewereine Here. In die verkondiging uit die profetiese literatuur moet hierdie spanning gehandhaaf bly. Belofte en eis moet onverswak verkondig word.

Natuurlik moet daar ook onthou word dat daar 'n verskil is tussen die situasie van toe en nou. Die hoorders van nou kan nie maar op dieselfde vlak geplaas word as die hoorders van toe nie (Helberg, 1983:111). Al word daar vir die Christelike gemeente gepreek, mag 'n Christologiese interpretasie nie vooraf die eksegese van 'n Ou-Testamentiese gedeelte bepaal nie (Verhoef, 1977:151).

In die prediking oor die profete vir vandag moet daar erns gemaak word met die vervuling al dan nie van profetiese uitsprake. Hiervoor is die viervoudige onderskeiding van Roberts (1979) baie bruikbaar. Die eerste groep is die profesiee wat reeds vervul is (Roberts, 1979:214). 'n Voorbeeld hiervan is Jeremia se profesie oor die vernietiging van die tempel in Jerusalem (Jer. $7: 14 ; 26: 1$ ). Die tweede groep is die profesiee wat nie vervul is nie en wat nie vervul sal word nie (Roberts. 1979:242-244). 'n Voorbeeld hiervan is die profesie in Esegiël $26: 7-14$ dat Nebukadneser Tirus sal inneem en verwoes, wat nooit gebeur het nie, soos gesien kan word in Esegièl $29: 17-20$. Hierdie soort profesiee wys weer op die voorwaardelike karakter van die $\mathrm{Ou}$-Testamentiese profesie. Op grond van die reaksie van die hoorders of ander omstandighede kan God 'n voorspelling kanselleer. Die derde groep is die profesieë waarvan die vervulling nog afgewag word, soos byvoorbeeld in profesiee wat handel oor die wêreld skoongemaak van sonde, soos Jesaja 11:6 - 9 (Roberts 1979:244-245). Die vierde groep is die profesiee wat reeds vervul is of waarvan die vervulling nog afgewag word, maar waarvan die vervulling nie as letterlik beskou kan word nie (Roberts, 1979:245-253). Roberts toon aan die hand van 'n vergelyking van Esegiel 37 - 48 met Openbaringe $20: 4-22: 5$ aan dat daar' $n$ verskil kan wees tussen die oorspronklike profesie en die vervulling (1979:245-247). 'n Ander faset hiervan is die saamtrekking van die toekoms in sulke profesieë. Hierna is daar reeds verwys. 
'n Profetiese bediening wat na die Ou-Testamentiese profete kyk, moet minstens die volgende insluit (vgl. Tucker, 1987:172-173):

* 'n Besef van roeping, van verantwoordelikheid teenoor God en teenoor en vir die wêreld.

* 'n Besef van die mag van die Woord, en selfs van menslike woorde, om die geskiedenis te verander.

* 'n Besef van die historiese konkreetheid in die godsdienstige lewe.

$\star$ 'n Besef van die sosiale, korporatiewe en institusionele dimensies van die mens se lewe. So ' $n$ besef is veral belangrik in 'n gemeenskap wat neig tot radikale individualisme, wat die mens beskou as 'n selfgemaakte wese.

^ 'n Sedelike bewustheid wat spesifiek en dapper is.

\section{PREDIKING OOR DIE PROFETIESE STOF}

Vir die eksegese met die oog op prediking uit die profetiese stof is daar deur baie skrywers riglyne gegee. Dit sal dus moontlik wees om 'n lang lys op te stel van sake wat in gedagte gehou moet word, maar dan sal dit waarskynlik nie in die praktyk van preekmaak veel sin hê nie. Daarom word hier volstaan met 'n aantal vrae wat aan en oor die spesifieke gedeelte gevra kan word om die belangrikste sake te ondervang. Vir die vrae is daar veral gebruik gemaak van riglyne vir die prediking en verdere opmerkings van Odendaal (1985:16-21), Dijk (1955:232-234),

Vriezen (1966:255), Helberg (1983:50, 110,111) en Verhoef (1977).

$\star$ Wat was die konkrete historiese situasie waarin die profeet opgetree het?

^ Wat was die objektiewe omstandighede wat die profetiese woord genoodsaak het?

Wat is die spesifieke aard van die profetiese boodskap?

^Watter rol speel digterlike taal en vaste vorme in die gedeelte?

$\star$ Wat was die wisselwerking tussen die profeet en sy gehoor, met inagneming van die verwagtinge van die gehoor?

- Wat het die bepaalde woord vir Israel beteken?

* Wat was die eie boodskap van die teksgedeelte en hoe pas dit in by die breëre boodskap van die Ou Testament?

^ Wat was die historiese situasie van sowel die oorspronklike adres as van die finale skrywer/samesteller en sy adres?

$\star$ Wat is die situasie rondom die vervulling van die spesifieke profetiese woord?

* Wat is die verskil tussen die situasie toe en nou?

$\star$ Hoe word God in sy persoonlike, lewende verhouding met sy volk in die gedeelte geopenbaar?

\ Hoe kan die boodskap Christosentries geinterpreteer word?

^Wat is die eskatologiese boodskap van die gedeelte, indien enige?

4. TOEPASSING VAN DIE RIGLYNE OP ESEGIEL $29: 1-16$.

Voordat die riglyne as sodanig gebruik kan word, moet die normale eksegetiese arbeid verrig word. Die riglyne kan reeds tydens die proses gebruik word om die eksegese te stuur, maar dit sal die beste wees om nadat die basiese eksegese gedoen is, die vrae van die riglyne een vir 
een te antwoord. By die toepassing daarvan op Esegiel $29: 1-16$ is daar bloot van vier kommentare, wat in my besit was, gebruik gemaak. Daar is aanvaar dat die dominee oor 'n aantal kommentare beskik, wat nie noodwendig die beste is wat beskikbaar is nie, en dat hy nie toegang het tot gespesialiseerde literatuur, soos tydskrifartikels, nie. Die kommentare is die van Cooke (1970), Eichrodt (1968), May (1956) en Taylor (1969). Daar sal nie in elke geval aangedui word waaraan die inligting vir 'n antwoord ontleen is nie. Vir baie van die antwoorde sal inleidings op die Ou Testament ook sinvol gebruik kan word. Die antwoorde sal so kort as moontklik gehou word.

4.1 Wat was die konkrete historiese situasie waarin die profeet opgetree het?

Esegiël was een van die ballinge wat in $597 \mathrm{vC}$ in ballingskap na Babiloniè weggevoer is. Gedurende die ballingskap is hy tot profeet geroep om God se woord aan die ballinge te verkondig. Sy boodskap was, veral voor die val van Jerusalem in 586, 'n woord van oordeel. Daar kan ook aanvaar word dat alhoewel die uitspraak teen Egipte gaan, dit tot die ballinge gerig was.

\subsection{Wat was die objektiewe omstandighede wat die profetiese woord genoodsaak het?}

Dit het meermale gebeur dat Israel in politieke nood op Egipte vertrou het, soos in die tyd van Hiskia (2 Kon 18:21). Volgens die datum van die profesie is dit uitgespreek toe Nebukadnesar Jerusalem beleër het, so agt maande voor die val en verwoesting van die stad. Dit was waarskynlik so dat die ballinge gehoop het dat Egipte sal help om Nebukadnesar te verslaan, sodat hulle weer kan terugkeer huis toe. Dit was 'n valse vertroue en Esegiël wou dit afbreek. Hy het die ondergang van Jerusalem verbind aan God se oordeel oor die sondes van die volk. Pleks daarvan om op Egipte te vertrou, moes hulle hulle bekeer en dan alleen sal genade moontlik wees.

4.3 Wat is die spesifieke aard van die profetiese boodskap?

Dit is ' $n$ oordeelsaankondiging.

4.4 Watter rol speel digterlike taal en vaste vorme in die gedeelte?

Die oordeel oor Egipte en die rede vir die oordeel word eers met twee metafore aangedui en daarna verder verklaar. Egipte se hoogmoed en die oordeel daaroor word aangedui met die beeld van die Nylkrokodil, wat buite sy natuurlike habitat - die Nyl - hulpeloos is. Die rede vir die oordeel word aangedui met die beeld van die riet, wat nie ondersteuning kan bied nie. Verder vertoon veral die eerste gedeelte van die uitspraak, vers 3 tot 7 die vorm van 'n klaaglied. Dit is heel ironies dat terwyl die ballinge op Egipte vertrou, Esegiël 'n klaaglied oor Egipte sing.

4.5 Wat was die wisselwerking tussen die profeet en sy gehoor, met inagneming van die verwagtinge van die gehoor?

Uit die res van Esegiel is dit duidelik dat die ballinge geleef het met die vertroue dat die ballingskap kortstondig sou wees. Hulle wou Esegiel 
se boodskap van oordeel en ondergang nie aanvaar nie, soos blyk uit die spreekwoorde van die volk wat in Esegiël $12: 22$ en 27 aangehaal word. Hierdie boodskap bevestig die oordeel wat vroeër deur Esegiël uitgespreek is.

\subsection{Wat het die bepaalde woord vir Israel beteken?}

Dit het hulle daarop gewys dat ' $n$ valse vertroue en mensgemaakte oplossings alleen hulle ellende vererger.

4.7 Wat was die eie boodskap van die teksgedeelte en hoe pas dit in by die breere boodskap van die Ou Testament?

Die boodskap is dat valse vertroue niks baat nie. Dit sluit aan by die boodskap van die soewereiniteit en heerskappy van God.

4.8 Wat was die historiese situasie van sowel die oorspronklike adres as van die finale skrywer/samesteller en sy adres?

Die situasie van die oorspronklike adres is in 4.1 behandel. Die boek van Esegiël is waarskynlik grotendeels in die ballingskap voltooi. Vir die ballinge van daardie tyd was sowel die val van Jerusalem as die oordeel oor Egipte al geskiedenis. Die gebeure het dus die woord van Esegiël bevestig en so roep hierdie gedeelte die volk op om tot vertroue op God alleen te kom. Dit is net Hy wat die ballingskap kan beëindig.

\subsection{Wat is die situasie rondom die vervulling van die spesifieke profetiese woord?}

In 568 - 7 het Nebukadnesar teen Egipte opgetrek. Die presiese uitslag van die aanval is onseker, maar dit is wel so dat Egipte nie weer 'n sterk moondheid geword het. Die vernedering van Egipte het dus wel plaasgevind.

\subsection{Wat is die verskil tussen die situasie toe en nou?}

Die situasie van 'n gemeente in Suid-Afrika vandag en die ballinge in Babilonië is radikaal verskillend. Tog is die gemeente deel van 'n nasie wat van binne en buite bedreig word. Die versoeking van mensgemaakte oplossings bly groot en daarom spreek die gedeelte vandag skerp dat alleen God se oplossing in vertroue op Hom gesoek moet word.

4.11 Hoe word God in sy persoonlike, lewende verhouding met sy volk in die gedeelte geopenbaar?

God openbaar Hom as die een wat in beheer is van die geskiedenis. Nebukadnesar word deur Hom gebruik as 'n instrument om sy oordeel te voltrek. Met valse vertroue het God geen genade nie.

4.12 Kan die boodskap Christosentries geïterpreteer word? Indien wel, hoe?

Christus en sy verdienste is die grond vir ons vertroue op God.

4.13 Wat is die eskatologiese boodskap van die gedeelte, indien enige? Deurdat die valse vertroue van die volk afgebreek word, wil Esegiël die volk daartoe bring om hulle vertroue op God te stel, wat op sy tyd weer hulle omstandighede sal verander. Aan die einde van die tyd sal alle mensgemaakte oplossings en valse vertroue vernietig word. 


\subsection{Tekskeuse}

Nadat die vrae beantwoord is, kan die tekskeuse gedoen word. Vers 16 is waarskynlik die beste, omdat die rede vir die oordeel oor Egipte daarin saamgevat word. Die tema vir die preek kan as volg geformuleer word: Ons valse vertroue word vernietig om ons te bring tot vertroue op God alleen. As hoofgedagtes kan die volgende gebruik word:

1. Wat is vertroue?

2. God vernietig valse vertroue.

3. Vertrou op God alleen.

In al drie die hoofgedagtes kan van die materiaal wat die agtergrond van die gedeelte duidelik maak, ingewerk word en die indeling leen hom ook baie goed tot toepaslike verklaring en verklarende toepassing.

\section{SLOT}

Die riglyne wat hier gegee is, geld as algemene riglyne, wat wel aanpassing nodig bet om by verskillende soorte stof aan te sluit. Dit kan egter veral daartoe dien om die omgang met die teksgedeelte sinvol te struktureer. Dit verminder die gevaar dat daar in die prediking uit die profete verval sal word in die plaas van gelyk-aan-tekens tussen Israel van toe en die gemeente van nou of in die moralisering oor die profete en wat hulle ervaar het.

\section{BIBLIOGRAFIE}

Aalders, W. 1983. Prophetische prediking. (In Van Oort, J. De Reuver. A \& Verduin, M, reds. 1983. Verbi divini minister. Feesbundel vir L. Kievit. Amsterdam: Ton Bolland. p. 7-28.)

Blenkinsop. J 1984. A history of prophecy in Israèl. London: SPCK

Bright, J. 1976a. A history of Israel, 2nd ed. London: SCM. (Old Testament Library.) 1976b. Covenant and promise. Philadelphia: Westminster.

Brueggemann, W. 1983. The book of Jeremiah. Portrait of the prophet. Interpretation, 37:130-145.

Carroll, RP. 1979. When prophecy failed. Reactions and responses to failure in Old Testament prophetic traditions. London: SCM.

1981. From chaos to covenant: Uses of prophecy in the book of Jeremiah. London SCM.

Childs, BS. 1978. The canonical shape of the prophetic literature. Interpretation, 32:46-55.

Clements, RE. 1982. The Ezekiel tradition: prophecy in a time of crisis (In Coggins, R. Phillips, A \& Knibb. MA, reds. 1982. Israel's prophetic tradition. Essays in honour of Peter R Ackroyd. Cambridge: University Press. p. 119-136.)

Cooke. GA. 1970. The book of Ezekiel. ICC. Edinburgh: Clark.

Crenshaw, JL. 1971. Prophetic conflict. Its effect upon Israelite religion. Berlin: De Gruyter. (BZAW 124.)

Dijk. K. 1955. De dienst der prediking. Kampen: Kok.

Eichrodt, W. 1968. Der Prophet Hezekiel. 3. Aufl. ATD. Gottingen: Vandenhoeck \& Ruprecht.

Gerssen, S. 1983. Oudtestamentische profetie en het Nieuwe Testament (In Van Oort, J, De Reuver, A \& Verduin, M, reds 1983. Verbi divini minister. Feesbundel vir L. Kievit. Amsterdam: Ton Bolland. p. 95-108.)

Helberg, JL. 1983. Verklaring en prediking van die Ou Testament. Potchefstroom: Potchefstroom Teologiese Publikasies.

Herrmann. S. 1971. Das prophetische Wort, fur die Gegenwart interpretiert. Evangelische Theologie, 31:650-664. 
Koch, K. 1982. The prophets, volume 1. The Assyrian period. London: SCM. 1983. The prophets, volume 2. The Babylonian and Persian periods. London: SCM.

Le Roux, JH. 1986. Tekste met 'n profetiese perspektief (In Deist, FE e.a. 1986. Woorde wat ver kom. Die literatuur van die Ou Testament I. Kaapstad: Tafelberg, p. 123-157.)

May, HG. 1956. Ezekiel. Interpreter's Bible VI : 41-338.

Nicholson, EW. 1970. Preaching to the exiles. A study in the prose tradition in the book of Jeremiah. Oxford: Basil Blackwell.

Odendaal, DH. 1985. Die Ou-Testamentiese profete in die prediking (In Burger, CW, Muller, BA \& Smit, DJ, reds. Riglyne vir prediking oor die profete. Woord teen die lig II/1. p. 7-20.)

Overholt, TW. 1977. Jeremiah and the nature of the prophetic process. (In Merrill, AL \& Overholt, TW, reds. Scripture in history and theology. Essays in honor of JC Rylaarsdam. Pittsburg: Pickwick. p. 129-150.) 1979a. Commanding the prophets: Amos and the problem of biblical authority. Catholic Biblical Quarterly, 41:517-532. $1979 \mathrm{~b}$. Jeremiah 2 and the problem of 'audience reaction'. Catholic Biblical Quarterly, 41:262-273. 1981. Prophecy: the problems of cross cultural comparison. Semeia, 19-22:55-78. 1982. Seeing is believing: the social setting of prophetic acts of power. Journal for the Study of the Old Testament, 23:3-31.

Preuss, HD. 1984. Das Alte Testament in christlicher Predigt. Stuttgart: Kohlhammer.

Roberts, JJM. 1979. A Christian perspective on prophetic prediction. Interpretation. 33:240-253.

Schmidt, WH. 1971. Die prophetische "Grundgewissheit". Evangelische Theologie, $31: 630-650$.

Taylor, JB. 1969. Ezekiel. Tyndale Old Testament Commentaries. London: Tyndale.

Tucker, GM. 1978. Prophetic speech. Interpretation, 32:31-45. 1987. The role of the prophets and the role of the church (In Petersen, DL. 1987. Prophecy in Israel. Search for an identity. Issues in religion and theology 10. Philadelphia/London: Fortress/SPCK. p. 159-174.)

Van Rooy, HF. 1988a. Eschatology and audience: The eschatology of Haggai. Old Testament Essays, 1/1:49-63. 1988b. Jeremia en die Woord in 'n tyd van krisis. Koers, 533:331-346.

Verhoef, PA. 1977. Die weg en brug tussen Ou-Testamentiese teks en prediking. Nederduits Gereformeerde Teologiese Tydskrif 18:145-157.

Vriezen, ThC. 1966. Hoofdlijnen der theologie van het Oude Testament. 3de druk. Wageningen: Veenman en Zonen.

Vriezen, ThC \& Van der Woude, AS. 1976. De literatuur van Oud-Israel. 5de druk. Wassenaar: Servire.

Wilson, RR. 1978. Early Israelite prophecy. Interpretation, 32:3-16.

Wolff, HW. 1978. Prophecy from the Eighth through the Fifth century. Interpretation. $32: 17-30$.

Zimmerli, W. 1978. The figure of the classical Old Testament prophet. Nederduits Gereformeerde Teologiese Tydskrif, 19:184-194. 